\section{Lenses and Mirrors to See the Universe}

Astronomy has changed a great deal since 1608, when the Dutch optician Hans Lippershey was refused a patent for his invention of the telescope. His patent was refused on the grounds that scientists had been using magnifying lenses since the 13th Century to study nature. Galileo heard of Lippershey's invention, though, and built one of his own. His observations eventually caused a great stir among the scientific community, not to mention extreme distress to the Catholic church.

Lippershey's type of telescope, with magnifying lenses mounted on the ends of a tube, is a refracting telescope. A century ago this year, one of the largest refractors in the world ( 36 inches in diameter) was installed on Mount Hamilton, near San Jose, California. The project to establish an observatory on Mount Hamilton-then a complete wilderness-was funded by the eccentric millionaire James Lick, who had made his fortune in the California gold rush.

The Alvan G. Clark company of Cambridge, Massachusetts, then the master telescope maker in the United States, created the 36-inch objective lens after several years of work. Thomas Fraser, one of the two men Lick designated to supervise the observatory's construction, traveled in winter from California to Massachusetts so he could accompany the completed lenses on their journey back to San Jose. Alvan Clark was careful to pack the precious lenses in a wooden box padded with human hair, which was then sealed inside a steel box to protect it on the long train ride. (The railroads gave the private car special priority.)

Once back in San Jose, Fraser transferred the box containing the lenses to a wagon, which he then took up the winding and treacherous road to the top of the mountain. Fraser and Richard Floyd, the second supervisor of the observatory's construction, installed the lens into the cell that would be mounted to the telescope.

Though the 36-inch refractor was ready for operation on December 31, 1887, the worst winter storm in decades struck Mount Hamilton. Four days later the sky finally cleared, but the dome was frozen into position and could not be rotated. Nevertheless, observers managed to focus on a star overhead, Aldebaran. Several days later, when the observers first looked at Saturn as it crossed the narrow window of visibility through the frozen dome, one of the assistants wrote that it was "the greatest telescope spectacle ever beheld by man."

The largest refracting telescope in existence today is the 40-inch refractor at Yerkes Observatory in Williams Bay, Wisconsin. It was installed in 1897 under the supervision of George Ellery Hale, a physics graduate of the Massachusetts Institute of Technology. Hale was running a small observatory in Chicago when he learned, at a scientific meeting in the summer of 1892 , that a pair of 40 -inch glass disks were available. They had been made by the Paris firm, Mantois, and had tested out to be optically perfect by the Alvan G. Clark company.

George Hale, ambitious and only 24, took his idea to William Harper, president of the University of Chicago, and con-

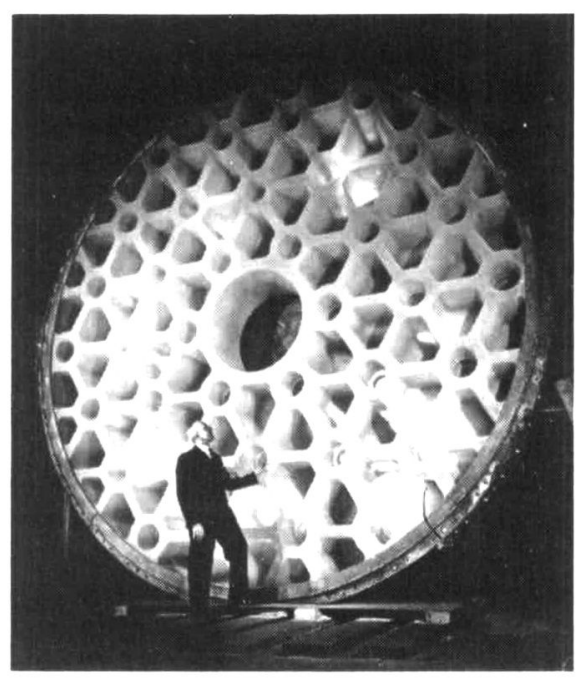

George McCauley of the Coming Glass Works with the completed 200-inch Pyrex blank for the "Hale telescope." McCauley worked on a different design for the mirror's back, making it ribbed and leaving empty cells to improve the glass's response to changing temperatures. Photo courtesy of the Dept. of Archives and Records Management, Corning Glass Works. vinced him of the need for a large telescope at the university's observatory. With the help of influential businessmen, Harper and Hale were able to convince Charles T. Yerkes, who had made his fortune with Chicago streetcars, to sponsor the project. "Build the observatory," Yerkes said. "Let it be the biggest in the world and send the bill to me."

Alvan Clark received the contract to build the telescope. The Warner \& Swasey Company of Cleveland, Ohio designed and constructed the telescope tube and mounting (which they completed in time for the World's Columbian Exposition held in 1893 in Chicago). The Clark company needed five years with the blank disks, grinding and polishing, until they achieved a two-element crown-and-flint objective lens. The lens was shipped from Massachusetts to Wisconsin in late Spring of 1897. Alvan Clark and his chief optical foreman, Carl Lundin, rode with the private railroad car to the site of the new observatory at Williams Bay. They supervised the installation of the lens into the mounting.

Hale wrote to Yerkes after the first observations had been made on May 21, 1897: "The brightness of...objects in the telescope is remarkable, and it is already clear that no other instrument in the world will show nebulae in so perfect a manner." The 40-inch refractor is still in service today at the Yerkes Observatory, unsurpassed in size for a refracting telescope. Because the lens of a refracting telescope can be supported only along the edges, glass disks larger than 40 inches in diameter distort and tend to sag in the center; also, their sheer thickness absorbs too much starlight.

A second type of telescope, the reflector, uses a mirror instead of a glass lens as the objective. The most common type of reflector was developed by Sir Isaac Newton in 1704. Since a mirror's shape can be supported along one entire side as well as the edges, reflecting telescopes can be made much larger than refractors.

After his work at Yerkes, George Hale turned to a massive reflecting telescope project. Hale's father, wealthy from inventing elevators used in many tall buildings in Chicago and around the world (including the Eiffel Tower), donated a 60 -inch glass blank for the mirror of a large telescope. Andrew Carnegie, steel millionaire, also provided funding, and by 1908 the 60 -inch reflecting telescope was in operation on Mount Wilson in California. For the second time in his life, Hale created the largest telescope in the world.

Even before the 60 -inch telescope was completed, though, Hale sought more 
funding for an even larger reflecting telescope-100 inches in diameter.

The subsequent 100 -inch "Hooker Telescope" was named for John D. Hooker, a local businessman who supported Hale's efforts. Hooker gave Hale $\$ 45,000$ to begin work on the mirror at a time when no one was certain such a large mirror could even be made, considering the difficulties that had been encountered in making the 60inch mirror. The French Plate Glass Company (St. Gobain, France)-which had cast the 60 -inch mirror-received the contract.

The casting for the mirror was a glass blank weighing five tons. On cooling, the glass exhibited numerous air bubbles between the layers of glass as they had been poured into the mold. Company experts called it a failure...two subsequent castings turned out even worse. Undaunted, Hale decided that air bubbles would have little to do with the functioning of the mirror. $\mathrm{He}$ asked that the first blank be shipped to him anyway. When it arrived in Pasadena, California, Hale's optics expert expressed his doubts too, pointing out that the mirror's surface would expand and contract unevenly because of the bubbles. Hale put the mirror in storage for more than a year. Another optics expert, Dr. Arthur L. Day of the Carnegie Institution, traveled out to look at it. He claimed that the bubbles would actually prevent the mirror from distorting.

That was all the optimism Hale needed...he ordered the work to begin again. Opticians took nearly six years to grind and polish the mirror's surface. Though World War I intervened, stalling construction of the observatory for several years, the 100-inch Hooker telescope finally showed its first image in November 1917. Many great astronomical discoveries were made with the Hooker telescope.

Recurring illness finally forced Hale to retire five years later as director of the observatory. Trying to relax, he wrote several articles for popular magazines, among them "The Possibilities of Large Telescopes" for Harper's. "Star light is falling on every square mile of the earth's surface, and the best we can do at present is to gather up and concentrate the rays that strike an area 100 inches in diameter."

Why not build a 200 -inch mirror?

Hale suggested that it could be done, and (after Hale's unblemished record of achievement) sponsors flung themselves at the project with apparent recklessness. But finding money was not the difficult part-how was such a huge glass blank to be cast? The 100-inch mirror blank had been poured from plate glass, but plate
The largest refracting telescope in existence today is the 40 -inch refractor at Yerkes Observatory in Williams Bay, Wisconsin.

glass had too high a coefficient of expansion, which would make the quality of astronomical images suffer.

Hale's first choice was pure quartz. For five years, engineers at General Electric (Lynn, Massachusetts) attempted to cast a fused-quartz mirror blank. They eventually managed a 60-inch blank at enormous cost, and suggested that a 200 -inch would be much more difficult and costly.

Hale's next choice was Pyrex from Corning Glass. George McCauley took charge of the project and cast successively larger and larger blanks, beginning with a 26 inch, then a 30-inch. McCauley also worked on a different design for the mirror's back, making it ribbed and leaving empty cells to improve the glass's response to changing temperatures. He used firebrick cores during the casting to leave the empty cells, but the cement holding the bricks in place did not withstand the heat of the molten glass. The firebricks came loose. He tried another anchoring method using firebrick dowels, which allowed him to pour a 30-inch ribbed blank, but the dowels, too, failed on the 60 -inch blank. Then McCauley tried steel bolts...successfully with the 60 -inch blank, and then with the 120-inch blank. (Incidentally, the "practice" castings each went off to become a mirror for other telescopes around the continent.)

The first attempt to pour the 200-inch blank was made on March 25, 1934. The massive Corning oven took two weeks just to melt the 65 tons of Pyrex for the casting. McCauley developed dome-shaped ovens to cover the mold and keep the glass at the

\section{In 1608 Dutch optician Hans Lippershey was refused a patent for his invention of the telescope.}

proper temperature. Reporters, scientists, and onlookers gathered for the event. Workers spent 10 hours manipulating huge ladles of molten Pyrex to fill the mirror mold. But during the pouring several of the firebrick spacers came loose and ruined the casting.

McCauley was successful with the second disk on December 2, 1934. The disk remained in a special annealing oven at a constant temperature for two months, then at a cooling rate for eight months. On March 26, 1936, the cooled glass disk was shipped from Corning (with much fanfare) on a specially made railroad car. Traveling at 25 miles per hour, routed around cities and high-traffic areas, the mirror blank arrived in Pasadena, California on April 10.

Grinding of the mirror progressed with eight sizes of grit, two sizes of aluminum oxide, and water and rouge for the final polishing. George Hale died during the years of grinding, confident that the 200inch telescope would be finished soon. World War II intervened, though, and the grinding and polishing was not finished until late 1947.

Remember that all this work was just to provide a base for the highly reflective aluminum film, no more than a thousand atoms thick, that was to be vacuum-coated on the surface of the mirror. (Even today, the aluminum coating must be removed every three years, the Pyrex beneath cleaned, and a new layer of aluminum applied in a vacuum tank.) Astronomer Edwin Hubble first used the 200 -inch mirror at the Mt. Palomar observatory on January 26, 1948. Now, 40 years after its first use, the 200-inch "Hale Telescope" has served astronomy by opening up the universe and allowing a host of discoveries.

Mirror design has become even more innovative in recent years. The European Southern Observatory's New Technology Telescope is now nearing completion: 141 inches in diameter, but only 9.5 inches thick, it is so flexible that its shape must be maintained by an array of computeractivated supports. The Keck Telescope on Mauna Kea, Hawaii will be the world's largest telescope at 10 meters in diameterbut instead of being made of a single giant mirror, the Keck telescope consists of 36 hexagonal-shaped mirror segments all computer-positioned into a precise hyperboloid shape and acting together as a single mirror. Creating mirrors for large systems with such rigid specifications will continue to reflect a challenge to materials scientists for many years. 


\section{MATERIALS RESEARCH SOCIETY 1988 MRS Fall Meeting Symposium Proceedings Special Pre-Publication Prices Available Only Through March 1, 1989}

Volume 128

Processing and Characterization of Materials Using lon Beams

Editors: Lynn E. Rehn, Joe E. Greene, Fred A. Smidt, 1989

ISBN: 1-55899-001-1 Order Code: 128

MRS Members $\$ 39.00 \quad$ U.S. List $\$ 44.00 \quad$ Foreign $\$ 49.00$

Volume 129

Laser and Particle Beam Chemical Processes on Surfaces

Editors: A. Wayne Johnson, G.L. Loper, T.W. Sigmon, 1989

ISBN: 1-55899-002-X Order Code: 129

MRS Members $\$ 39.00 \quad$ U.S. List $\$ 44.00$

Foreign $\$ 49.00$

Volume 130

Thin Films: Stresses and Mechanical Properties

Editors: John C. Bravman, William D. Nix, David M. Barnett, David A. Smith, 1989

ISBN: 0-55899-003-8 Order Code: 130

MRS Members $\$ 35.00 \quad$ U.S. List $\$ 43.00 \quad$ Foreign $\$ 48.00$

Volume 131

Chemical Perspectives of Microelectronic Materials

Editors: Mihal E. Gross, John T. Yates, Jr., Joseph Jasinski, 1989

ISBN: 0-55899-004-6 Order Code: 131

MRS Members $\$ 42.00 \quad$ U.S. List $\$ 48.00 \quad$ Foreign $\$ 54.00$

Volume 132

Multicomponent Ultrafine Microstructures

Editors: B.H. Kear, D.E. Polk, R.W. Siegel, 1989

ISBN: 1-55899-005-4 Order Code: 132

MRS Members $\$ 35.00 \quad$ U.S. List $\$ 42.00 \quad$ Foreign $\$ 50.00$

Volume 133

High Temperature Ordered Intermetallic Alloys

Editors: C.C. Koch, C.T. Liu, N.S. Stoloff, A. I. Taub, 1989

ISBN: 1-55899-006-2 Order Code: 133

$\begin{array}{lll}\text { MRS Members } \$ 42.00 & \text { U.S. List } \$ 50.00 & \text { Foreign } \$ 59.00\end{array}$

Volume 134

The Materials Science and Engineering of Rigid-Rod Polymers

Editors: W. Wade Adams, Ronald K. Eby, Donald E. McLemore, 1989

ISBN: 1-55899-007-0 Order Code: 134

MRS Members $\$ 42.00 \quad$ U.S. List $\$ 50.00 \quad$ Foreign $\$ 58.00$

Volume 135

Solid State lonics

Editors: Gholamabbas Nazri, Robert A. Huggins, Duward F. Shriver, P. T. Wu

1989

ISBN: 1-55899-008-9 Order Code: 135

$\begin{array}{lll}\text { MRS Members } \$ 39.00 & \text { U.S. List } \$ 46.00 & \text { Foreign } \$ 55.00\end{array}$

Volume 136

Fly Ash and Coal Conversion By-Products: Characterization, Utilization and

Disposal V

Editors: E.E. Berry, R. T. Hemmings, G.J. McCarthy, 1989

ISBN: 1-55899-009-7 Order Code: 136

MRS Members $\$ 38.00 \quad$ U.S. List $\$ 43.00$

Foreign $\$ 51.00$

Volume 137

Pore Structure and Permeability of Cementitious Materials

Editors: Lawrence R. Roberts, Jan P. Skalny, 1989

ISBN: 1-55899-010-0 Order Code: 137

MRS Members $\$ 35.00 \quad$ U.S. List $\$ 42.00$

Foreign $\$ 50.00$

Volume 138

Characterization of the Structure and Chemistry of Defects in Materials

Editors: Bennett C. Larson, Manfred Ruhle, David N. Seidman, 1989

ISBN: 1-55899-011-9 Order Code: 138

$\begin{array}{lll}\text { MRS Members } \$ 39.00 & \text { U.S. List } \$ 45.00 \quad \text { Foreign } \$ 54.00\end{array}$

Volume 139

High Resolution Microscopy of Materials

Editors: William Krakow, Fernando A. Ponce, David J. Smith, 1989

ISBN: 1-55899-012-7 Order Code: 139

MRS Members $\$ 38.00$

U.S. List $\$ 42.00$

Foreign $\$ 50.00$
Volume 140

New Materials Approaches to Tribology: Theory and Applications

Editors: Larry E. Pope, Larry Fehrenbacher, Ward O. Winer, 1989

ISBN: 1-55899-013-5 Order Code: 140

MRS Members $\$ 39.00 \quad$ U.S. List $\$ 45.00 \quad$ Foreign $\$ 52.00$

Volume 141

Atomic Scale Calculations in Materials Science

Editors: J. Tersoff, D. Vanderbilt, V. Vitek, 1989

ISBN: 1-55899-014-3 Order Code: 141

MRS Members $\$ 34.00 \quad$ U.S. List $\$ 40.00$

Foreign $\$ 48.00$

Volume 142

Nondestructive Monitoring of Materials Properties

Editors: John Holbrook, Jean Bussiere, 1989

ISBN: 1-55899-015-1 Order Code: 142

MRS Members $\$ 34.00 \quad$ U.S. List $\$ 40.00$

Foreign $\$ 48.00$

Volume 143

Synchrotron Radiation in Materials Research

Editors: John H. Weaver, John Gland, Roy Clarke, 1989

ISBN: 1-55899-016-X Order Code: 143

MRS Members $\$ 35.00 \quad$ U.S. List $\$ 38.00$

Foreign $\$ 45.00$

Volume 144

Advances in Materials, Processing and Devices in III-V Compound

Semiconductors

Editors: Devendra K.Sadana, Lester Eastman, Russell Dupuis, 1989

ISBN: 1-55899-017-8 Order Code: 144

$\begin{array}{ll}\text { MRS Members } \$ 34.00 & \text { U.S. List } \$ 40.00\end{array}$

Foreign $\$ 48.00$

Extended Abstracts

Code EA-16

Graphite Intercalation Compounds; Science and Applications

Editors: M.S. Dresselhaus, G. Dresselhaus, 1989

MRS Members $\$ 8.00 \quad$ U.S. List $\$ 10.00 \quad$ Foreign $\$ 10.00$

Code EA-17

Fractal Aspects of Materials: Disordered Systems

Editors: David A. Weitz, Leonard M. Sander, Benoit B. Mandelbrot, 1989

$\begin{array}{lll}\text { MRS Members } \$ 8.00 & \text { U.S. List } \$ 10.00 & \text { Foreign } \$ 10.00\end{array}$

Code EA-18

Selected Topics in Electronic Materials

Editors: B.R. Appleton, W.L. Brown, D.K. Biegelsen, J.A. Knapp, 1989

MRS Members $\$ 8.00 \quad$ U.S. List $\$ 10.00 \quad$ Foreign $\$ 10.00$

The prices listed here are available only through

March 1, 1989. Prices after this date will be

higher. Order Now!

Publications Department

Materials Research Society

9800 McKnight Road, Suite 327

Pittsburgh, Pennsylvania 15237

Telephone (412) 367-3012

Fax (412) 367-4373 